Delamater, E. D., Hunter, M. E., Szybalski, W. \& Bryson, V. (1955). J. gen. Microbiol. 12, 203-212

\title{
Chemically Induced Aberrations of Mitosis in Bacteria
}

\author{
By E. D. DeLAMATER and MARY ELIZABETH HUNTER
}

Section on Cytology and Cytochemistry, School of Medicine, University of Pennsylvania, Philadelphia, Pennsylvania, U.S.A.

AND W. SZYBALSKI* AND V. BRYSON

The Biological Laboratory, Cold Spring Harbor, Long Island, New York, U.S.A.

SUMMARY: Bacillus megaterium was studied cytologically during exposure to a number of toxic agents, including known mitotic inhibitors. Many antibiotics and sodium $p$-aminosalicylate at inhibitory concentrations induced an increase in the size and optical density of the stained nuclei, and a preponderance of configurations resembling metaphase and anaphase stages. Continued chromosome reduplication results in the establishment of a transient polyploidy. Isoniazid and benzimidazole bring about a decrease in the amount of stainable material in the nucleus. Penicillin and bacitracin produce no obvious changes in the nuclear pattern in this organism. The significance of the aberrations observed is discussed. Further support for the similarity of bacterial nuclei to the nuclei of higher organisms is provided.

In most of its fundamental aspects the bacterial cell seems to be very similar to the cells of higher plants and animals. Despite the establishment of similarities in biochemistry, physiology, and the mechanisms which control heredity in bacteria and larger cells, the cytology of the bacterial cell remains partially controversial. The existence of nuclei in the bacterial cell was proven only during the last two decades, but the nuclear structure and divisional mechanism are still subjects of discussion. Technical and interpretative difficulties are in large part responsible for this situation. The chromosomal components of even the larger bacteria have dimensions which lie at the limit of resolution of the light microscope. In consequence, these structures can be seen with only limited clarity as discrete entities even when their orientation is optimal. Technical problems, such as the presence of masking ribonucleic acid (RNA) in the cytoplasm and the susceptibility of the cell structure to distortion by fixatives, drying, and room temperature dehydration, have been the source of much confusion.

Reliance on analogy with higher forms has been used as a basis of criticism by Lamanna \& Mallette (1953) in their consideration of the exposition of mitotic processes in bacteria by DeLamater (1953). Obviously our detailed knowledge of the mitotic cycle could not have been formulated through investigations on the bacterial cell, because of its small size. However, a belief that filamentous or rod-like structures in the bacterial nucleus are similar in nature to the more easily observed chromosomes of higher organisms would be strengthened if the alleged analogy of Lamanna \& Mallette holds true under

* Present address: Institute of Microbiology, Rutgers University, New Brunswick, New Jersey. 
a variety of different experimental conditions. An answer to the question, 'Do these similar structures in the bacterial nucleus behave similarly?' may thus be arrived at.

The study of mitosis in bacteria under the action of so-called mitotic poisons and other inhibitors represents an alternative set of conditions, and might supply additional evidence for the reality of mitotic configurations in the bacterial nucleus. Levan (1953) wrote: 'If similar deviations were induced in mitosis of yeast as were known to occur in higher plants after such (c-mitotic) treatment, it would be an indication that the Feulgen-positive bodies observed in yeast were really chromosomes undergoing mitosis.' (Levan (1954) suggested the use of the term c-mitotic 'in a broad sense for all morphologically discernible disturbance of the spindle function irrespective of any notions as to the mode of action underlying the effects...'.) Similar reasoning may be used for bacteria. In addition to this theoretical implication, it will be shown here that the action of certain toxic substances provides the following technical advantages: (1) the percentage of cells with mitotic figures increases from a small fraction to almost $100 \%$, thus eliminating the necessity of selecting single cells for the demonstration of metaphase spindles in bacteria; (2) the optical density of stained nuclear material is increased. The present study deals with the general cytological effect of several antibiotics, sodium $p$ aminosalicylate, isoniazid and the purine analogue benzimidazole.

\section{METHODS}

Organisms. Bacillus megaterium, the strain employed by DeLamater \& Hunter (1951), was used as the test organism. Mutants resistant to high concentrations of the toxic agents (Szybalski, 1954) were exposed to the given agents, together with wild type.

Media. Suspensions of up to $6 \times 10^{8}$ cells $/ \mathrm{ml}$. were prepared by growing the organisms in double strength nutrient broth (Difco), 16 g. desiccated medium/l., for $6 \mathrm{hr}$. at $34^{\circ}$ in small bottles with agitation. The agar medium had the following composition: nutrient broth desiccated (Difco), 8 g.; yeast extract (Difco), 1 g.; NaCl, 5 g.; NZ amine A (a peptone supplied by 'Sheffield Farms', Sheffield Chemical Co., Norwich, New York, division of National Dairy Products Inc.), 5 g.; agar 20 g.; demineralized water, 1 l.

Methods of application of toxic substances. Appropriate volumes of solution were added to $10 \mathrm{ml}$. portions of melted agar medium in $\frac{1}{2} \mathrm{oz}$. screw-cap bottles and mixed. Plates were prepared according to the gradient plate method of Szybalski (1952). This method was used because it permitted the study of the action of the toxic agent over a wide range of concentrations. The agent was incorporated only into the upper wedge of agar, providing approximately a tenfold range in concentration along the gradient. The concentration of the toxic agent was adjusted to demonstrate both growth and inhibition on the same plate. The figures indicating concentration ranges in the following list have the following significance: $1 / 0$, indicates that $1 \mu \mathrm{g} . / \mathrm{ml}$. of toxic substance was added to the upper wedge of agar, and none $(0 \mu \mathrm{g} . / \mathrm{ml}$. $)$ to the lower wedge. 
The concentration on such a plate varies from about 1 to $0 \cdot 1 \mu \mathrm{g} . / \mathrm{ml}$. along the axis of the gradient. The following concentration ranges $(\mu \mathrm{g} . / \mathrm{ml}$.) were employed: oxytetracycline hydrochloride (terramycin), 2/0 and 1/0; chlortetracycline hydrochloride (aureomycin), 0.5/0; streptomycin sulphate, 3/0; sodium $p$-aminosalicylate, 2000/0; carbomycin, 4/0; erythromycin, 0.5/0; neomycin sulphate, $0 \cdot 1 / 0$; viomycin sulphate, 40/0; chloramphenicol, 5/0; potassium penicillin, 1000/0; bacitracin, $0 \cdot 2 / 0$; isoniazid, 2000/0; benzimidazole, 2000/0.

After pre-drying of the surface, the suspension of organisms was streaked over the agar with a pipette in about five streaks parallel to the axis of the gradient. The plates were then incubated and the organisms examined cytologically after various periods of exposure. Any resistant colonies were cut out from the agar before making smears. Experiments with different concentrations of agents, time of action and recovery were all done on a single plate, thus eliminating a major source of variation. All strains were examined under comparable conditions in the absence of any toxic agent.

Termination of exposure. Recovery of the organisms from the inhibitory action of certain toxic agents was permitted by either of the two following procedures: (1) awaiting spontaneous decay of certain antibiotics; (2) superimposing on plain agar the strip of agar bearing the streak on its upper surface, thus permitting the toxic agent to diffuse downward and decrease the concentration at the level of the bacterial cells.

Cytological procedure. A strip of agar bearing a streak of organisms and extending along the entire gradient was cut out. This was divided into four portions of equal length, corresponding to increasing concentration of toxic agent. Following fixation of the cells in the vapour of $\mathrm{OsO}_{4}(1 \%$ solution) for 3 min., smears were made on cover-slips marked so as to make possible identification of the range and direction of increase of the drug concentration. The cells were then hydrolysed in $\mathrm{N}-\mathrm{HCl}$, stained in thionin- $\mathrm{SO}_{2}$, and dehydrated in the cold according to the method of DeLamater (1951).

Photomicrography. Observations were made with a Bausch \& Lomb research microscope equipped with an achromatic condenser of 1.4 N.A., a $\times 90$ apochromatic oil-immersion objective of 1.4 N.A., and $\times 12.5$ compensating oculars. Photographs were taken with a Bausch \& Lomb L camera on Kodak Panatomic-X film, using a camera length of 20 in. A Bausch \& Lomb interference filter of wave-length $570 \mathrm{~m} \mu$. provided maximum contrast. The final magnification of the illustrations is $\times 4500$.

\section{RESULTS}

The normal course of nuclear division in Bacillus megaterium was described by DeLamater \& Mudd (1951) and interpreted as mitosis. Within each rod the nuclear divisions are more or less synchronous, but nuclei in interphase and in all stages of mitosis are found in every microscopic field. Metaphase and anaphase seem to be of shortest duration, as judged by the relative numbers of each stage and by comparison with several higher organisms in which the 
length of the individual stages of the mitotic cycle is more easily defined. Exposure to the toxic agents produced one of the following gross effects on the optical density of stained nuclear material: (1) an increase in density (the majority of toxic agents tested); (2) no major change (bacitracin, penicillin); (3) a decrease in density (isoniazid, benzimidazole). Only in cases (1) and (2) was it practical and possible to detect and study induced aberrations in the nuclear divisional mechanism.

All the toxic agents comprising the following diverse group of drugs produced certain common effects: chlortetracycline, oxytetracycline, streptomycin, sodium $p$-aminosalicylate, neomycin, carbomycin, erythromycin, viomycin, chloramphenicol. The first effect was an increase in the optical density of stained nuclear material obtained in the vicinity of the inhibitory concentrations (see Szybalski, 1954) and at higher concentrations. Accompanying this change were aberrations in the nuclear divisional mechanism, manifested as an increased incidence of figures which were interpreted as metaphase and anaphase, and as possibly indicating an arrest at this stage of mitosis. When Bacillus megaterium was treated for $2 \mathrm{hr}$. at inhibitory concentrations or higher of oxytetracycline, chlortetracycline, sodium $p$-aminosalicylate, neomycin, carbomycin, erythromycin, or chloramphenicol, the percentage of nuclei in metaphase or anaphase approached $100 \%$ (Pl. 1, fig. 1; Pl. 2, fig. 4; Pl. 3, figs. 6, 9; Pl. 4, figs. 10, 11). It was hardly possible to document this effect adequately by photographs because of limitations imposed by a short depth of the field. Below the inhibitory concentration the percentage of affected nuclei decreased very rapidly to zero, so that the thresholds of growth inhibition and the cytological effect were almost identical. Viomycin and streptomycin did not show similar effectiveness until after about 4 hr. (Pl. 2, fig. 5; Pl. 4, fig. 12). In the inhibited cells the bodies interpreted as centrioles were of increased size and optical density, and often gave evidence of reduplication (Pl. 4, figs. 10, 12).

With continued exposure the nuclei increased in size and density by elongation in the axis of the bacillus, becoming sausage-shaped (Pl. 1, fig. 2; Pl. 3, fig. 7). Within such condensed masses individual structures resembling chromosomes could not usually be defined. In occasional nuclei it was possible to count more than the haploid number of such chromosomes (Pl. 2, fig. 4; Pl. 3, fig. 7). These observations suggested that deoxyribonucleic acid (DNA) synthesis and chromosome reduplication were continuing in the absence of nuclear division. The term polyploidy is used here and in two previous papers (DeLamater, 1953; DeLamater, Hunter, Szybalski, Minsavage \& Bryson, 1953) to describe this condition. However, because a resting polyploid nucleus is not reconstituted and perpetuated, as will be shown presently, the more explicit designation 'transient polyploidy' is fitting. It serves to distinguish the condition from the permanent polyploidy induced in higher forms by c-mitotic substances, e.g. colchicine.

Mutants of Bacillus megaterium resistant to higher concentrations of the toxic agents showed none of the described effects in the same range of concentration of the given agent. 
In addition to differences in rapidity of action, other characteristics made it possible to distinguish certain of the toxic agents in this group by their cytological effects. Sodium $p$-aminosalicylate apparently effected an inhibition of centriolar migration, as evidenced by the unipolar nature of the spindle in many of the arrested nuclei (Pl. 4, fig. 11). This retardation of migration of the centrioles was also produced, but to a lesser degree, by other members of this group of agents. An interesting feature of cells arrested by carbomycin was the striking increase in dye affinity of the septum in bicellular rods (Pl. 3, fig. 6).

Recovery of Bacillus megaterium from the inhibitory effects was followed only after chlortetracycline and oxytetracycline treatment. While the toxic agents were being removed as described in Methods, the arrested cells were examined cytologically. A high percentage of the cells recovered. The sausageshaped nuclear mass took on increasing length throughout an elongating cell, and at the same time lobulation, arising from constrictions in the nuclear membrane, became progressively apparent (PI. 2, fig. 3). Within the individual lobules, of which there were as many as eight per nucleus, three contracted chromosomes, constituting the haploid complement, could be observed. The haploid nuclei, once separated, proceeded to completion of the mitotic process. With the re-institution of cell division, the picture became indistinguishable from the normal.

Isoniazid and benzimidazole. With respect to the optical density of stained nuclear material, these two toxic agents produced an effect opposite to that of the first group of inhibitors. There was a decrease in dye affinity of the chromosomes (Pl. 4, figs. 13, 14) to the extent that definition of detail was lost, and no aberrations in their structure or mechanism of separation could be detected. The cytological effect became apparent below the inhibitory concentrations, and increased in severity with increasing concentration of agent. In a proportion of cells isoniazid induced a striking increase in dye affinity of the cell membrane.

Penicillin and bacitracin. No obvious effects on the nuclear density or structure were noted during exposure of Bacillus megaterium to these compounds at any concentration on the gradients. Failure of penicillin to produce aberrations might have been due to the high penicillinase production of this organism.

\section{DISCUSSION}

The action of certain antibiotics on plant and animal cells has been studied by others and found to interfere with mitosis. Wilson (1950) and Wilson \& Bowen (1951) noted characteristic mitotic upset in root tips of Allium cepa treated with streptomycin, neomycin, chlortetracycline, oxytetracycline, or chloromycetin; penicillin did not have any significant effect. One of the most striking deviations from the normal was 'failure of the metaphase-anaphase sequence'. Division figures, especially at prometaphase and metaphase, showed clumping and stickiness of the chromosomes, which were shorter than normal. Apparent delay in dissolution of the nuclear membrane was also noted. Recovery of A. cepa root tips was possible only when the toxic agent was chloramphenicol, 
and no evidence of polyploidy was found. However, Wilson \& Bowen stated that polyploidy is a theoretical possibility as a consequence of this c-mitotic arrest of normal mitosis.

Keilová (1948) and Keilová-Rodova (1950) studied the influence of streptomycin and chlortetracycline on the nuclei of cells in tissue culture, and observed a slight increase in the duration of metaphase and increased pyknosis and rhexis of chromosomes at metaphase. Woolley (1944) showed growth inhibition in yeasts and bacteria by benzimidazole. In chick tissue cultures exposed to this compound, Hughes (1952) reported an inhibitory effect on mitotic activity. Duncan \& Woods (1953) treated onion root tips with benzimidazole and concluded that this substance inhibited both initiation of mitosis and DNA synthesis.

Studies on the effect of antibiotics on bacterial cytology have dealt mainly with penicillin, which has been shown to induce large body formation (see Dienes \& Weinberger, 1951; or Tulasne, 1951, for a review of the literature). Where other antibiotics were also studied, they were usually reported to produce a very different effect from that of penicillin. The cytological effects of various antibiotics have been investigated by numerous workers (Tulasne, Vendrely \& Minck, 1948; Werner \& Kellenberger, 1948; Scanga, 1948 $a, b$; Levaditi \& Henry, 1948; Welsch, Nihoul \& Demelenne-Jaminon, 1948; Eisenstark, Ward \& Kyle, 1950; Preuner, von Prittwitz \& Gaffron, 1951; Bringmann, 1952; Steinberg, 1952; Pulvertaft, 1952, 1953; DePoux, 1953; Kellenberger, 1953; Bergersen, 1953; Brieger, Cosslett \& Glauert, 1953). Where nuclear phenomena were investigated, increase in size and density of the nuclei in the presence of chlortetracycline, oxytetracycline, or chloramphenicol was often reported (Steinberg, 1952; Kellenberger, 1953). Preuner, von Prittwitz and Gaffron concluded that nuclear division, but not cell division, was blocked by streptomycin. Bringmann noted that in the presence of this antibiotic Escherichia coli produced large amounts of nucleic acid on a medium on which nucleic acid production was usually minimal.

In the present study the toxic agents have been classified on the basis of their over-all effect on the optical density of stained nuclear material of Bacillus megaterium. Most of them produced a pronounced increase of optical density, while isoniazid and benzimidazole had the opposite effect. A possible parallel exists between this inverse action and the partial antagonism of streptomycin by isoniazid (Szybalski \& Bryson, 1953) and by benzimidazole (Szybalski, unpublished).

Associated with the increase in stainable nuclear material is an inhibition of nuclear division, manifested as a rise in the relative number of stages which resemble anaphase and telophase mitotic configurations. So effective is this inhibition that the percentage of nuclei apparently in metaphase and anaphase approaches $100 \%$. The basis of the mitotic arrest may lie in malfunction of the spindle apparatus. Toxic agents which produce this effect, therefore, could be classified with the group of mitotic inhibitors which interferes with both anaphase movement and chromosome reconstruction in higher forms but, unlike colchicine, does not prevent the formation of the spindle. 
It follows from the increase in nuclear size and optical density, and from counts of the putative chromosomes, that DNA synthesis and chromosome reduplication may proceed in Bacillus megaterium in the presence of toxic agents comprising one group of agents, even though mitosis be arrested. The resulting polyploid state persists only as long as the inhibitor is present, and is, therefore, the property of a nucleus in a stage of inhibited division. This is termed 'transient polyploidy' to distinguish it from the permanent polyploidy induced in higher forms by colchicine and certain other c-mitotic substances. Following early removal of the tetracyclines a majority of cells recovered from the bacteriostatic effect of these drugs. Restoration of the haploid state takes place directly by a process of reduction, microscopically observable as occurring by multiple constriction or sacculation of the nuclear membrane, which appears to persist throughout the mitotic cycle.

It is presumably no mere coincidence that agents known to inhibit mitosis in higher organisms may arrest nuclear division in almost $100 \%$ of treated bacteria. The effect of benzimidazole indicates a further analogy between the nuclei of bacteria and those of higher forms, now evident under both normal and abnormal environmental conditions. The behaviour of the bacterial nucleus in the presence of known mitotic inhibitors thus provides supporting evidence for the existence of chromosomes in bacteria, and their distribution by a mitotic mechanism. For economy of both hypothesis and terminology, the concept of bacterial mitosis is again advanced as consistent with an increasing number of observations. Complete verification or refutation of this view will require the accumulation of extensive additional information, and may require further advances in technique and instrumentation. These analogies, both under normal conditions and in the presence of a number of inhibitors, together with the fact that the cytological effects of the inhibitors were demonstrated in nearly $100 \%$ of the bacterial nuclei, seems to indicate that similarities in the nuclear division of bacteria and higher forms are more than coincidental.

We are gratefully indebted to Dr N. Bohonos of Lederle Laboratories Division for chlortetracycline hydrochloride; to Dr F. W. Tanner, Jun., Dr G. L. Hobby, and Dr W. Alan Wright of Chas. Pfizer and Co. for oxytetracycline hydrochloride, viomycin sulphate, and carbomycin; to Dr L. B. Hobson of E. R. Squibb and Sons for streptomycin sulphate; to Dr O. E. Graessle of Merck Institute for sodium $p$-aminosalicylate; to Dr H. A. Nelson of the Upjohn Company for neomycin sulphate; to Dr R. J. Hickey of Commercial Solvents Corp. for bacitracin; to Dr N. E. Rigler and Dr M. A. Darken of Heyden Chemical Corporation for penicillin; to Dr Q. Bartz of Parke, Davis and Co. for chloramphenicol; to Dr M. J. McGuire of the Lilly Research Laboratories for erythromycin; and to Dr J. A. Aeschlimann of Hoffman-LaRoche for isoniazid. This study was supported in part by a grant from the Atomic Energy Commission, Contract AT(30-1)-1341, and by a grant from Eli Lilly and Co. 


\section{REFERENCES}

Bergersen, F. J. (1953). Cytological changes induced in Bacterium coli by chloramphenicol. J. gen. Microbiol. 9, 353.

Brieger, E. M., Cosslett, V. E. \& Glauert, A. M. (1953). Action of antibiotics on avian tubercle bacilli studied with the electron microscope. Nature, Lond. 171, 211.

Bringmann, G. (1952). Licht- und elektronenmikroskopische Studien an AntibioticaFormen von Coli-Bakterien. Zbl. Bakt. (1. Abt. Orig.), 157, 577.

DeLamater, E. D. (1951). A staining and dehydrating procedure for the handling of microorganisms. Stain Tech. 26, 199.

DeLamater, E. D. (1953). Structure and division of the bacterial nucleus. VI Congr. int. Microbiol. Symp. Cytology, p. 108.

DeLamater, E. D. \& Hunter, M. E. (1951). Preliminary report of true mitosis in the vegetative cell of Bacillus megaterium. Amer. J. Bot. 38, 659.

Dellamater, E. D., Huniter, M. E., Szybalski, W., Minsavage, E. \& Bryson, V. (1953). Observations on the influence of various inhibitors including colchicine, sodium $p$-aminosalicylate, and several antibiotics of the tetracycline, erythromycin and streptomycin groups on the bacterial nucleus. Riass. Commun. VI Congr. int. Microbiol. 1, 48.

DeLamater, E. D. \& Mudd, S. (1951). The occurrence of mitosis in the vegetative phase of Bacillus megaterium. Exp. Cell Res. 2, 499.

DePoux, R. (1953). Influence de divers antibiotiques sur la morphologie des Azotobacter. Ann. Inst. Pasteur, 84, 641.

Dienes, L. \& Weinberger, H. J. (1951). The $L$ forms of bacteria. Bact. Rev. 15, 245.

Duncan, R. E. \& Woods, P. S. (1953). Some cytological aspects of antagonism in synthesis of nucleic acid. Chromosoma, 6, 45.

Eisenstark, A., Ward, Jun., C. B. \& Kyle, T. S. (1950). A study of large bodies in Azotobacter agile. J. Bact. 60, 525.

HugHes, A. (1952). Effect of purines and related substances upon cells in a chick tissue culture. Exp. Cell Res. 3, 108.

KeILová, H. (1948). The effect of streptomycin on tissue cultures. Experientia, 4, 483.

KeILOvá-Rodova, H. (1950). The effect of aureomycin on tissue cultures. Experientia, 6,428 .

KeluenBerger, E. (1953). Les formes caractéristiques des nucléoides de $\boldsymbol{E}$. coli et leurs transformations dues a l'action d'agents mutagènes-inducteurs et de bactériophages. VI Congr. int. Microbiol. Symp. Cytology, p. 45.

Lamanna, C. \& Mallette, M. F. (1953). Basic Bacteriology. Baltimore, Maryland, U.S.A.: Williams and Wilkins.

Levaditi, C. \& Henry, J. (1948). Mise en évidence de modifications morphologiques et tinctoriales des micro-organismes soumis à l'influence des antibiotiques et des bactériophages par la méthode des décalques. Rev. Immunol. 12, 193.

Levan, A. (1958). Discussion of E. D. DeLamater's paper. Cold Spr. Harb. Symp. quant. Biol. 16, 409.

Levan, A. (1954). Colchicine-induced c-mitosis in two mouse ascites tumours. Hereditas, 40, 1.

Preuner, R. von Pritwwitz \& Gaffron, J. (1951). Über Feulgen-positive Körper in Bazillen und Bakterien und ihr Verhalten gegenüber Streptomycin und Penicillin. Zbl. Bakt (1. Abt. Orig.), 157, 244.

Pulvertart, R. J. V. (1952). The effect of antibiotics on growing cultures of Bacterium coli. J. Path. Bact. 64, 75.

Pulvertaft, R. J. V. (1953). The $L$ form of bacteria in relation to antibiotics. J. Path. Bact. 65, 175. 
Journal of General Microbiology, Vol. 12, No. 2

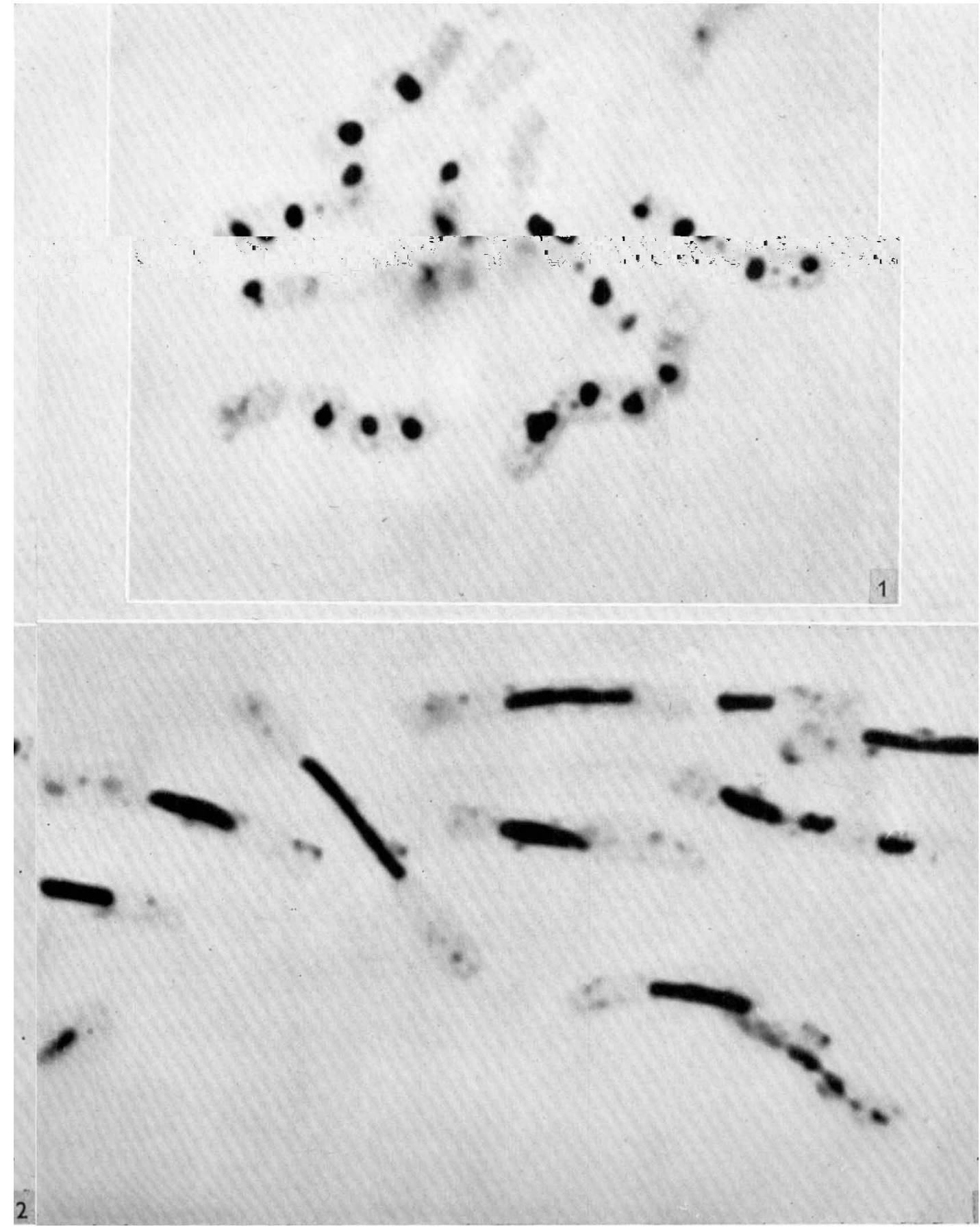

F. D. Delamaten et al,--Chemicalig induced mitotic ablerhations. Piate 1 
Journal of General Microbiology, Vol. 12, No. 2

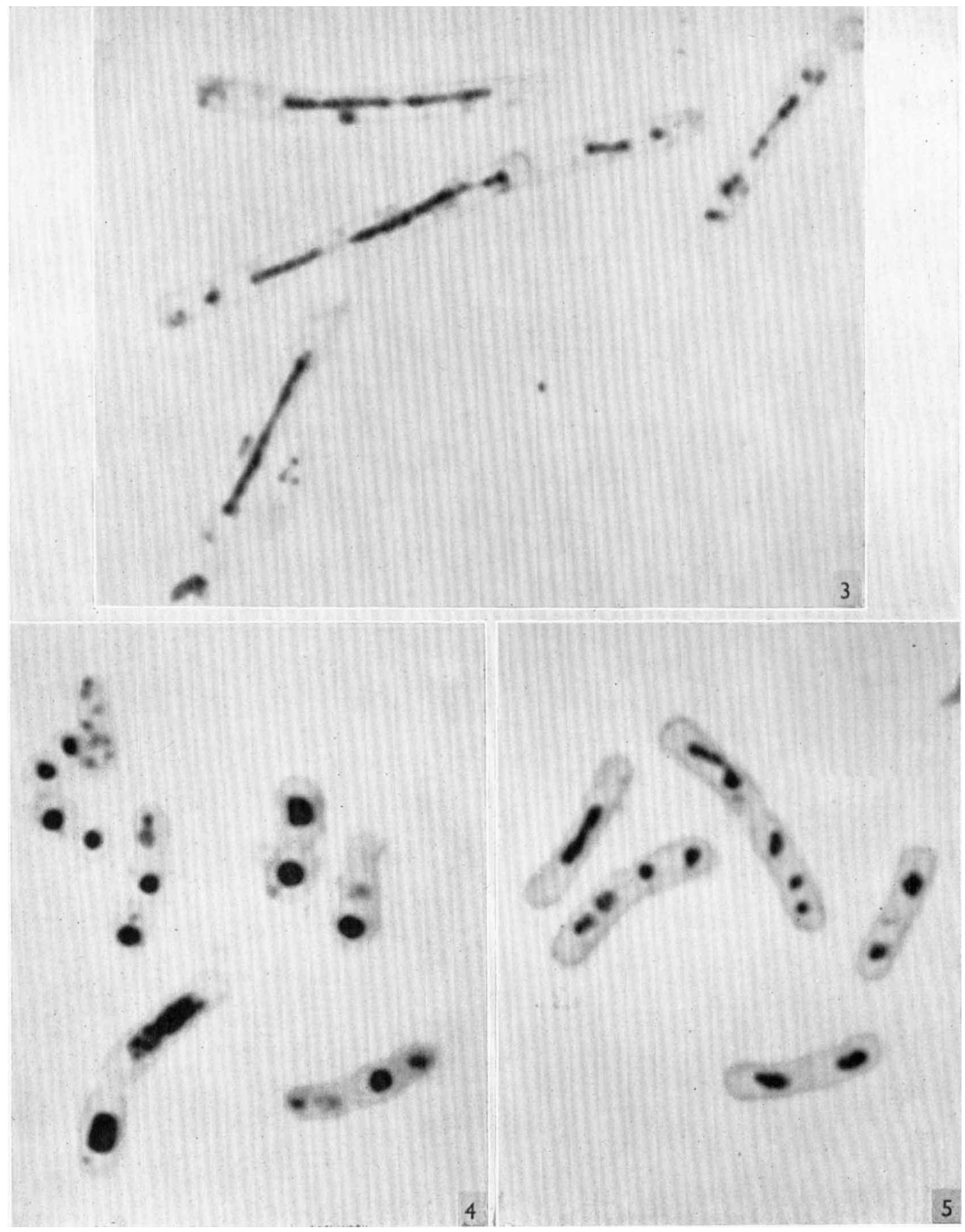

E. D. Delamater et $a L$-Chemically induced mitotic aberrations. Plate 2 
Journal of General Microbiology, Vol. 12, No. 2

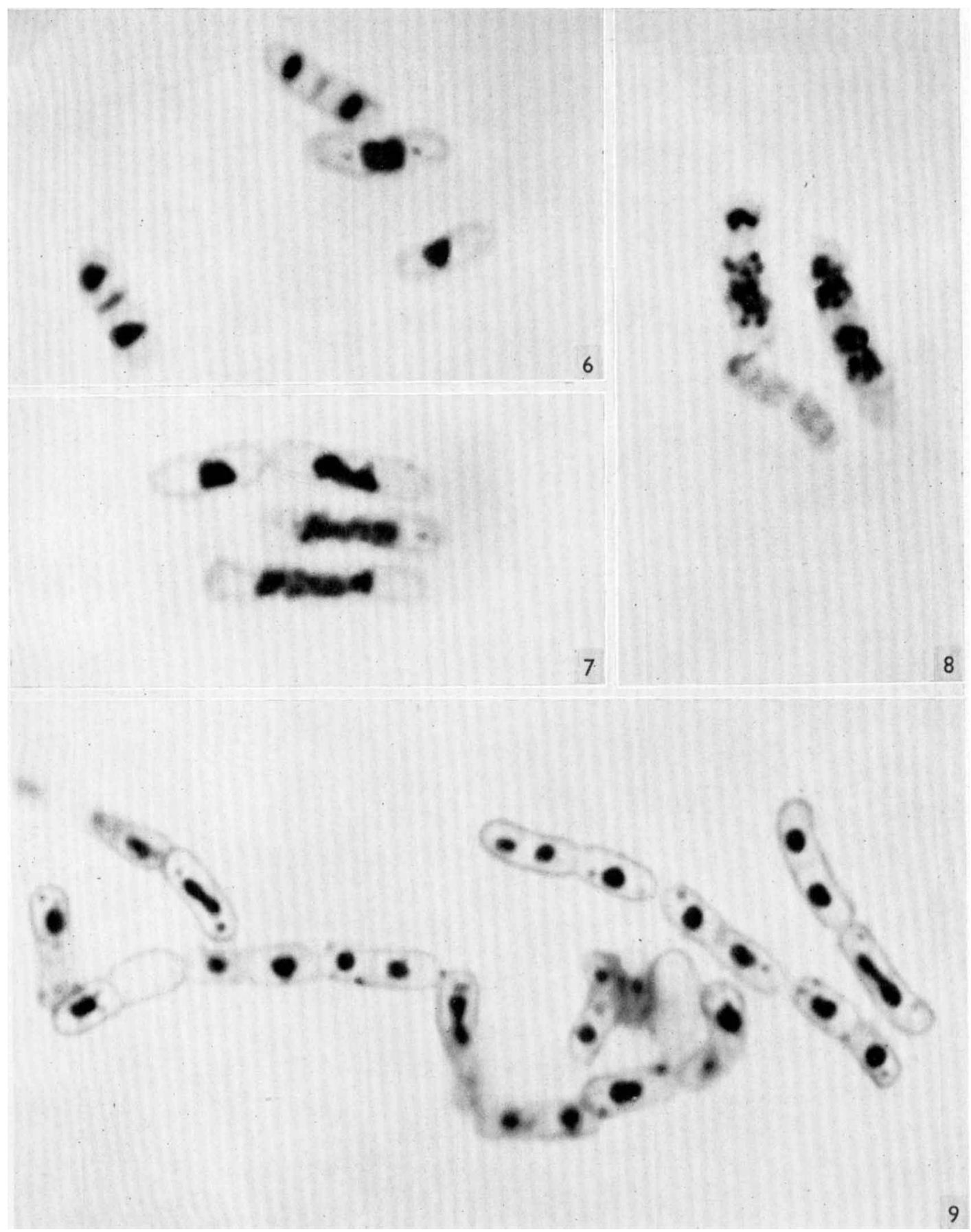

E. D. Delamater et al.-Chemically indecled mitotic aberrations. Piate: 3 
Journal of General Microbiology, Vol. 12, No. 2

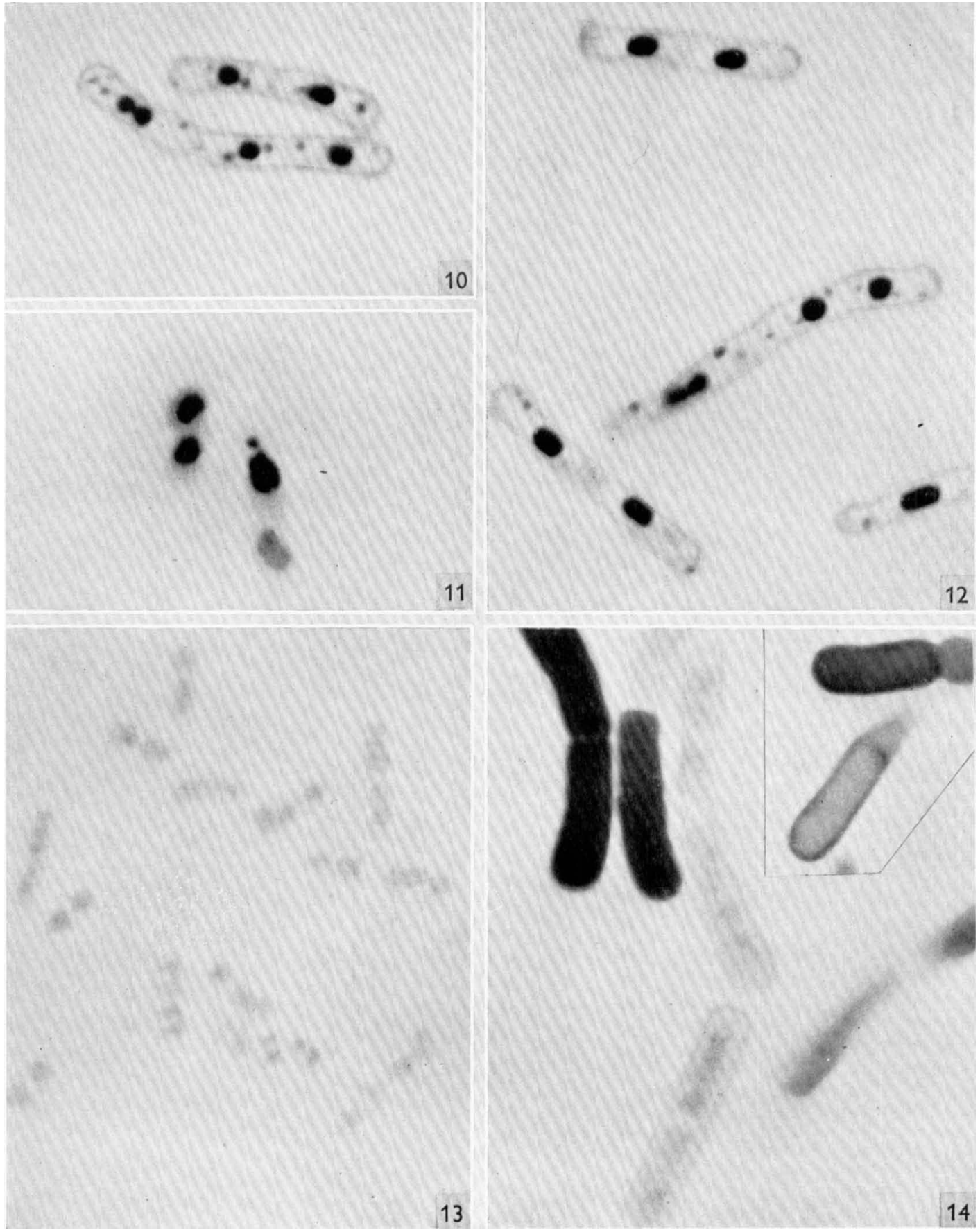

F. D. DeI amater et al.-Chimicalify induced mitotic aberkations. Plate 4 


\section{Chemically induced mitotic aberrations}

SCanga, F. (1948 $a$ ). L'azione della streptomicina, del solfone e di alcuni disinfettanti sui germi, studiate al microscopio elettronico. R.C. Ist. sup. Sanit. 11, 970.

ScaNGa, F. (1948b). L'azione della streptomicina sui germi, osservata al microscopio elettronico con la tecnica delle ombre. R.C. Ist. sup. Sanit. 11, 980.

Steinberg, B. (1952). Les modifications de la structure interne de $\boldsymbol{E}$. coli B sous l'action d'antibiotiques. Schreiz. Z. Path. 15, 432.

SzYBaLSKr, W. (1952). Gradient plate technique for study of bacterial resistance. Science, 116, 47 .

SzYBaLSKr, W. (1954). Genetic studies on microbial cross resistance to toxic agents. IV. Cross resistance of Bacillus megaterium to forty-four antimicrobial drugs. Appl. Microbiol. 2, 57.

SzYBalski, W. \& Bryson, V. (1953). Conditional antagonism between isoniazid and other antibacterial agents. Amer. Rev. Tuberc. 68, 280.

Tulasne, R. (1951). Les formes $\mathrm{L}$ des bactéries. Rev. Immunol. 15, 223.

Tulasne, R., Vendrely, R. \& Minck, R. (1948). Noyaux bactériens et streptomycine. C.R. Soc. Biol., Paris, 142, 1012.

Welsch, M., Ninoul, E. \& Demelenne-Jaminon, G. (1948). Étude cytologique de l'action de quelques antibactériens sur Escherichia coli. C.R. Soc. Biol., Paris, $142,1452$.

Werner, G. H. \& Kellenberger, E. (1948). Le role du microscope électronique dans l'étude du mode d'action des antibiotiques. Bull. Acad. suisse Sci. méd. 4, 263.

Wilson, G. B. (1950). Cytological effects of some antibiotics. J. Hered. 61, 226.

Wilson, G. B. \& Bowen, C. C. (1951). Cytological effects of some more antibiotics. J. Hered. 62, 251.

Woolley, D. W. (1944). Some biological effects produced by benzimidazole and their reversal by purines. J. biol. Chem. 152, 225.

\section{EXPLANATION OF PLATES}

Plate 1. Bacillus megaterium, exposed to various toxic agents, stained by DeLamater's method. Magnification, $\times \mathbf{4 5 0 0}$.

Fig. 1. $2 \mathrm{hr}$. exposure to inhibitory concentration of oxytetracycline. Increased optical density of stained nuclei in metaphase.

Fig. 2. $5 \mathrm{hr}$. exposure to inhibitory concentration of oxytetracycline. Elongation of nuclear mass.

Plate 2. Bacillus megaterium, exposed to various toxic agents, stained by DeLamater's method. Magnification, $\times \mathbf{4 5 0 0}$.

Fig. 3. $18 \mathrm{hr}$. exposure to oxytetracyline. Stages in recovery of cells due to spontaneous decay of antibiotic.

Fig. 4. 2 hr. exposure to inhibitory concentration of chlortetracycline. Cell in lower left shows stage in elongation of dense nuclear mass, in which more than three chromosomes are visible.

Fig. 5. $4 \mathrm{hr}$. exposure to inhibitory concentration of streptomycin.

Plate 3. Bacillus megaterium, exposed to various toxic agents, stained by DeLamater's method. Magnification, $\times 4500$.

Fig. 6. $2 \mathrm{hr}$. exposure to inhibitory concentration of carbomycin. Heavily stained septa.

Fig. 7. $5 \mathrm{hr}$. exposure to inhibitory concentration of carbomycin. Elongation of arrested nuclei reveals multiplicity of chromosomal components.

Fig. 8. $4 \mathrm{hr}$. exposure to inhibitory concentration of erythromycin. Arrested nuclei show re-elongation of chromosomes.

Fig. 9. 2 hr. exposure to inhibitory concentration of neomycin. 
Plate 4. Bacillus megaterium, exposed to various toxic agents, stained by DeLamater's method. Magnification, $\times 4500$.

Fig. 10. $2 \mathrm{hr}$. exposure to inhibitory concentration of chloramphenicol.

Fig. 11. $2 \mathrm{hr}$. exposure to inhibitory concentration of sodium $p$-aminosalicylate. Unipolar spindle.

Fig. 12. $4 \mathrm{hr}$. exposure to inhibitory concentration of viomycin.

Fig. 13. $2 \mathrm{hr}$. exposure to inhibitory concentration of benzimidazole. Reduced dye affinity of nuclei.

Fig. 14. $2 \mathrm{hr}$. exposure to inhibitory concentration of isoniazid. Reduced dye affinity of nuclei. Increased dye affinity of membrane of several cells.

(Received 26 August 1954) 